\title{
Nebulised salbutamol does have a protective effect on airways in children under 1 year old
}

\author{
C O'CALLAGHAN, A D MILNER, AND A SWARBRICK
}

Department of Child Health, University Hospital, Nottingham

SUMmARY Ten infants under the age of 1 year each of whom gave a history of recurrent wheezing attacks were studied with a total body plethysmograph. All the infants were free of wheeze when studied and were sedated with chloral hydrate. All 10 showed a significant deterioration in lung function when given nebulised water for two minutes with an increase in airways resistance and a decrease in specific conductance at one and five minutes after nebulisation compared with baseline readings. Measurements returned to baseline values within 15 minutes. When the same amount of nebulised water was given 20 minutes after nebulised salbutamol, however, there was no significant deterioration in lung function at one and five minutes after administration of nebulised water.

We conclude that the airways were protected against the bronchoconstricting effect of nebulised water by the $\beta_{2}$ adrenoreceptor stimulant salbutamol.

Many doctors believe that $\beta_{2}$ adrenoreceptor stimulants have little or no effect on the airways of infants under the age of 1 year. These children do, however, have $\beta_{2}$ adrenoreceptors ${ }^{\prime}$ and smooth muscle $^{2}$ in their airways and theoretically should respond to $\beta_{2}$ adrenergic stimulants. Nebulised water has a bronchoconstricting effect on asthmatic children and adults, ${ }^{3-7}$ and we have found that it also causes bronchoconstriction in wheezy infants (unpublished data).

The present study was designed to find out if nebulised salbutamol protects the airways of wheezy infants. Nebulised water was used as a bronchoconstricting challenge.

\section{Patients and methods}

Patients studied were under 1 year old and attending this hospital for routine assessment. All had had more than two wheezy episodes in the preceding months. Table 1 shows their age, sex, and history of bronchiolitis. At the time of the study all were clinically well and at least four months had elapsed since their bronchiolitic illnesses. Each study was done in the outpatient clinic, all patients were awake, and allowed home within three hours of arrival.

The infants were sedated with chloral hydrate $(120 \mathrm{mg} / \mathrm{kg})$, and thoracic gas volume and airways resistance were measured with total body plethysmography. ${ }^{8-11}$ The total body plethysmograph had a capacity of 260 litres, and a servo controlled heating system maintained the face mask, shutter system, and rebreathing bag at $36^{\circ} \mathrm{C}$. Thoracic gas volume was measured at the end of inspiration, and the tidal volume was subtracted before calculation. The children were nursed supine and firm latex masks applied to their faces. The dead space of each mask was $88 \mathrm{ml}$. There was a bias flow of air at $5 \mathrm{l} /$ minute to the face mask. Signals were relayed to the axis of a cathode ray oscilloscope, all readings were made by the same observer,

Table 1 Details of 10 infants studied

\begin{tabular}{rrrll}
\hline Patient No & $\begin{array}{l}\text { Age } \\
\text { (months) }\end{array}$ & $\begin{array}{l}\text { Weight } \\
(\mathrm{kg})\end{array}$ & Sex & $\begin{array}{l}\text { History } \\
\text { of } \\
\text { bronchiolitis }\end{array}$ \\
\hline 1 & 11 & $10 \cdot 5$ & Male & Yes \\
2 & 10 & $9 \cdot 1$ & Male & No \\
3 & 9 & $8 \cdot 3$ & Female & Yes \\
4 & 9 & $8 \cdot 0$ & Male & No \\
5 & 9 & $10 \cdot 2$ & Male & Yes \\
6 & 10 & $8 \cdot 9$ & Femalc & Yes \\
7 & 6 & $8 \cdot 3$ & Male & Yes \\
8 & 9 & $8 \cdot 2$ & Male & Yes \\
9 & 10 & $11 \cdot 0$ & Male & Yes \\
10 & 11 & $11 \cdot 2$ & Female & No \\
\hline
\end{tabular}


and calculations were made by standard techniques. Multiple breaths were analysed in each case. Baseline measurements of thoracic gas volume and airways resistance were calculated.

The infants were then given water nebulised ultrasonically at a temperature of $21^{\circ} \mathrm{C}$ from an Intersurgical Variosonic II nebuliser at setting number 3 through the face mask for two minutes with a flow rate of $5 \mathrm{l} /$ minute. Thoracic gas volume and airways resistance were measured at regular intervals until they were stable (which was defined as no change in readings over a five minute period). The dense mist occasionally escaped from the space between mask and face owing to an inadequate seal during the first few seconds of nebulisation. The mask was adjusted accordingly and the study restarted with an adequate seal. The infant was then given salbutamol $(0.5 \mathrm{ml}$ salbutamol respirator solution in $1.5 \mathrm{ml}$ normal saline) through a Cirrhus nebuliser chamber at a flow rate of $6 \mathrm{l} /$ minute for five minutes. Thoracic gas volume and airways resistance were measured at regular intervals until they had returned to baseline measurements. Nebulised water was then given through the ultrasonic

Table 2 Baseline readings in airways resistance and specific conductance, and changes after two minute challenge with nebulised water in 10 infants

\begin{tabular}{|c|c|c|c|c|c|c|c|c|c|}
\hline \multirow{3}{*}{$\begin{array}{l}\text { Patient } \\
\text { No }\end{array}$} & \multicolumn{3}{|c|}{ Baseline readings } & \multicolumn{6}{|c|}{ Time after challenge (minutes) } \\
\hline & \multirow{2}{*}{$\begin{array}{l}\text { Thoracic } \\
\text { gas } \\
\text { volume } \\
\text { mllkg }\end{array}$} & \multirow{2}{*}{$\begin{array}{l}\text { Airways } \\
\text { resistance }\end{array}$} & \multirow{2}{*}{$\begin{array}{l}\text { Specific } \\
\text { conductance }\end{array}$} & \multicolumn{2}{|l|}{1} & \multicolumn{2}{|l|}{5} & \multicolumn{2}{|l|}{10} \\
\hline & & & & $\begin{array}{l}\text { Airways } \\
\text { resistance }\end{array}$ & $\begin{array}{l}\text { Specific } \\
\text { conductance }\end{array}$ & $\begin{array}{l}\text { Airway } \\
\text { resistance }\end{array}$ & $\begin{array}{l}\text { Specific } \\
\text { conductance }\end{array}$ & $\begin{array}{l}\text { Airway } \\
\text { resistance }\end{array}$ & $\begin{array}{l}\text { Specific } \\
\text { conductance }\end{array}$ \\
\hline 1 & 17 & $17 \cdot 2$ & $0 \cdot 31$ & $25 \cdot 8$ & 0.21 & $33 \cdot 1$ & 0.16 & $17 \cdot 2$ & $(0) 31$ \\
\hline 3 & 25 & 21 & 0.22 & $21 \cdot 3$ & 0.23 & $30 \cdot 9$ & 0.17 & $25 \cdot 6$ & $(0 \cdot 20$ \\
\hline 4 & 28 & 21 & 0.21 & $22 \cdot 0$ & $0 \cdot 20$ & $27 \cdot 4$ & 0.17 & $21 \cdot 0$ & $(0.21$ \\
\hline 5 & 32 & 22 & 0.15 & $27 \cdot 3$ & $0 \cdot 10$ & $28 \cdot 8$ & $(0 \cdot 10$ & $21 \cdot 8$ & ()$\cdot 14$ \\
\hline 6 & 33 & $21 \cdot 5$ & 0.15 & $27 \cdot 6$ & $0 \cdot 12$ & $33 \cdot 7$ & $0 \cdot 10$ & $25 \cdot()$ & $0 \cdot 13$ \\
\hline 7 & 39 & $15 \cdot 5$ & 0.22 & $20 \cdot 3$ & 0.17 & $25 \cdot 3$ & 0.14 & $20 \cdot()$ & $(0.17$ \\
\hline 8 & 65 & 17 & 0.12 & $20 \cdot 3$ & $0 \cdot 10$ & $21 \cdot 4$ & $(0 \cdot 10$ & $17 \cdot 3$ & 0.12 \\
\hline 9 & 38 & 21 & $(0.11$ & $24 \cdot 8$ & 0.09 & $27 \cdot 4$ & 0.08 & $20 \cdot 9$ & 0.11 \\
\hline 10 & 17 & $21 \cdot 0$ & $(0 \cdot 25$ & $32 \cdot 0$ & $0 \cdot 15$ & $40 \cdot 7$ & 0.12 & $21 \cdot 0$ & $0 \cdot 25$ \\
\hline Mcan (SD) & $32 \cdot 5(12)$ & $20 \cdot 1(2 \cdot 5)$ & $(0 \cdot 19(0 \cdot 05)$ & $25 \cdot()(3 \cdot 8)$ & $0 \cdot 15(0 \cdot(05)$ & 3()$\cdot 1(5 \cdot())$ & $0 \cdot 12(0 \cdot(03)$ & $21 \cdot 3(26 \cdot())$ & $0.18(0 \cdot(0.5)$ \\
\hline
\end{tabular}

Airways resistance is reported as $\mathrm{cm} \mathrm{H}_{2} \mathrm{O} / \mathrm{l} / \mathrm{second}$.

Specific conductance is reported as $\mathrm{cm} \mathrm{H}_{2} \mathrm{O}^{-1} \mathrm{~s}^{-1}$.

Table 3 Baseline readings in airways resistance and specific conductance, and changes after two minute rechallenge given 20 minutes after nebulised salbutamol in 10 infants

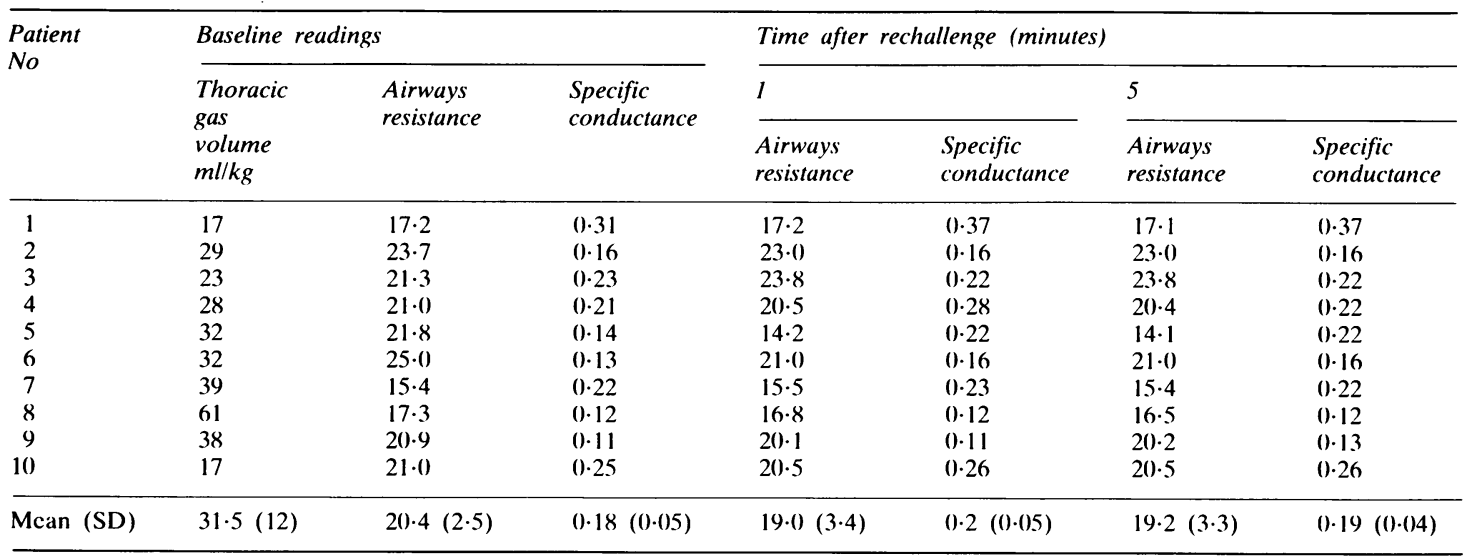

Airways resistance is reported as $\mathrm{cm} \mathrm{H}_{2} \mathrm{O} / \mathrm{l} / \mathrm{second}$.

Specific conductance is reported as $\mathrm{cm} \mathrm{H}_{2} \mathrm{O}^{-1} \mathrm{~s}^{-1}$. 
Nebulised salbutamol does have a protective effect on airways in children under 1 year old 481

nebuliser for two minutes as described previously. Thoracic gas volume and airways resistance were measured until they were stable. Each infant was monitored continuously with an oxygen saturation machine and an electrocardiogram. Specific conductance was calculated from the readings taken. A paired $t$ test was used to analyse the results.

The study was approved by the Nottingham University ethics committee. Informed parental consent was obtained for each of the studies.

\section{Results}

Baseline measurements of thoracic gas volume, airways resistance, and specific conductance are shown in table 2 together with the changes in airways resistance and specific conductance after the administration of nebulised water. All infants showed significant increases in airways resistance one minute after the water had been given $(p<0 \cdot 01)$ and five minutes after it had been given $(\mathrm{p}<0 \cdot 001)$; these had returned to baseline values after 10 minutes (fig 1). There were also significant decreases in specific conductance one minute after the water had been given $(p<0.01)$; and five minutes after it had been given $(p<0 \cdot 001)$; these had returned to baseline values after 10 minutes (fig 2 ).

When rechallenged with a similar amount of

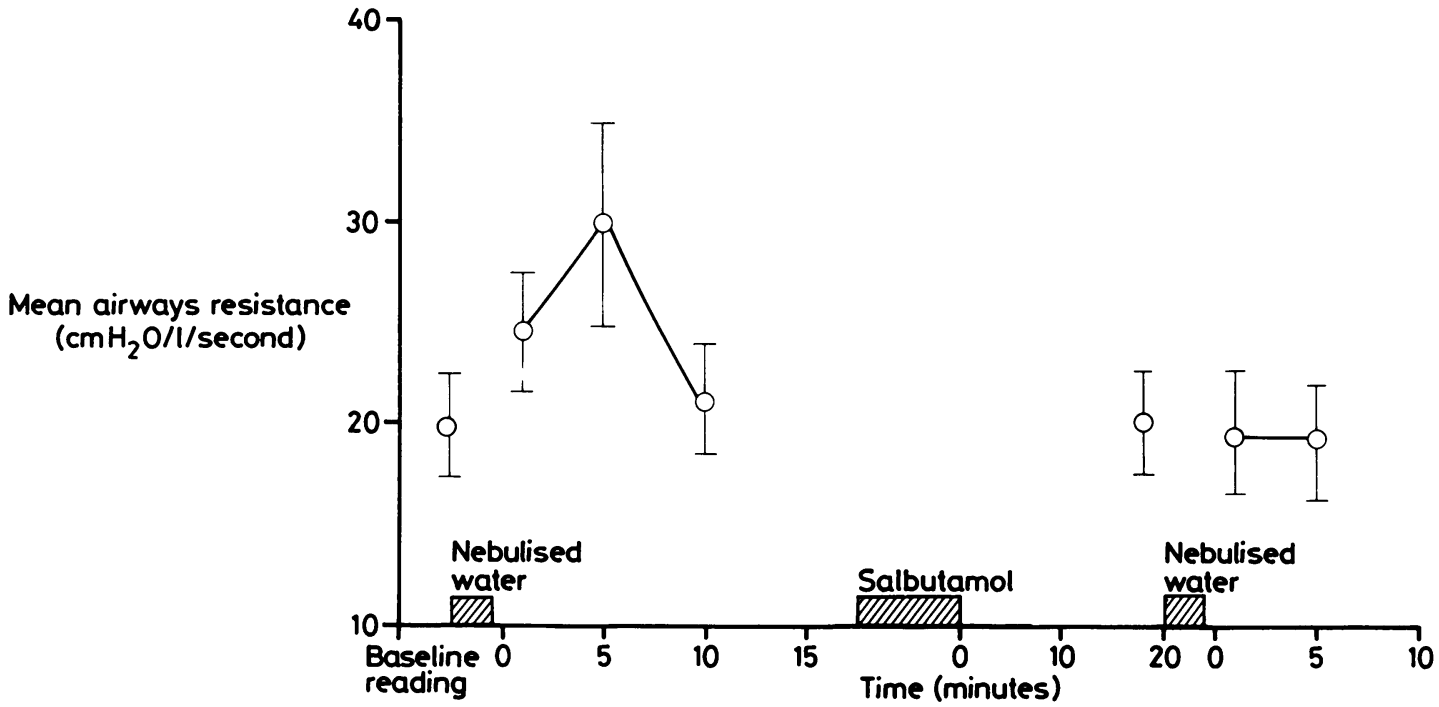

Fig 1 Mean (SD) airways resistance of 10 infants with history of wheezing showing changes after the administration of nebulised water and salbutamol.

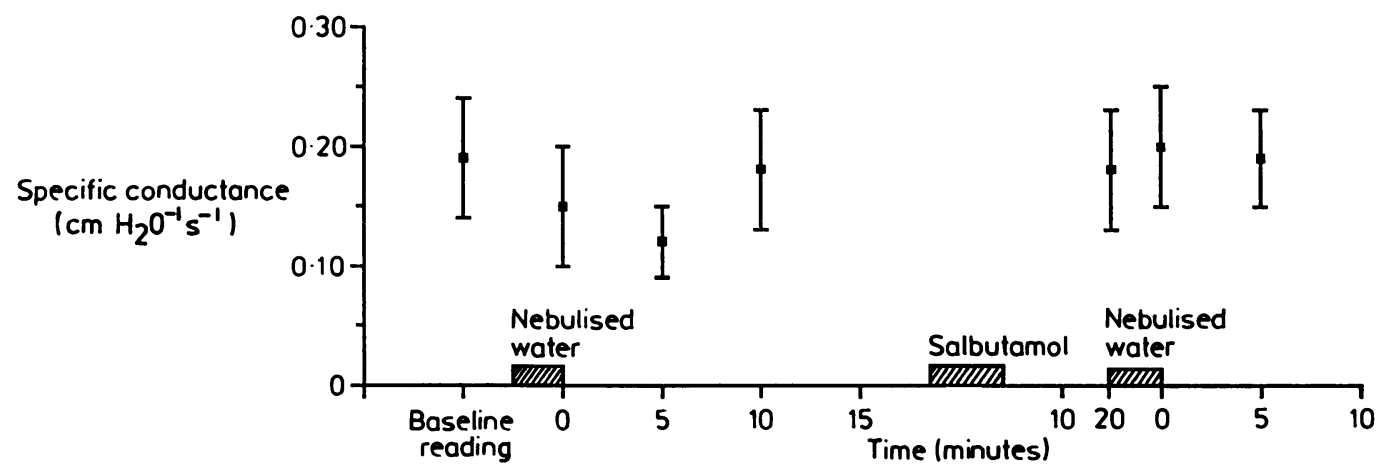

Fig 2 Mean (SD) specific conductance of 10 infants with history of wheezing showing changes after the administration of nebulised water and salbutamol. 
nebulised water 20 minutes after nebulised salbutamol had been given however, there were no significant changes in airways resistance $(p>0.5)$ or specific conductance ( $p>0 \cdot 5)$ (fig 1$)$. There were no significant changes in thoracic gas volume after any of the challenges.

There were no abnormalities in the electrocardiographic traces, and oxygen saturation did not fall below $84 \%$ in any of the patients during the study.

\section{Discussion}

Subjective clinical observations have suggested that nebulised bronchodilators are helpful in treating some wheezy infants. There is little evidence from clinical trials, however, to recommend treatment of such infants with bronchodilators. ${ }^{12-23}$

Nebulised water produces bronchoconstriction in asthmatic subjects. ${ }^{3-7}$ In the 10 infants we studied all of whom had history of wheezing, we confirmed that nebulised water in the regimen we gave caused bronchoconstriction. The measurements showing deterioration in lung function correlated well with the patients' clinical signs during the study. When rechallenged with the same amount of nebulised water 20 minutes after receiving nebulised salbutamol, however, there was no evidence of bronchoconstriction; the salbutamol had protected the airways.

Prendiville et al studied five infants and found that salbutamol had a similar protective effect when histamine was used as the challenge. ${ }^{1}$ The results of this and the present study show that $\beta_{2}$ adrenoreceptors do exist in infants.

The amount of nebulised water given is derived from the results of 20 studies we performed before this trial (unpublished data). We found that repeated stimuli with nebulised water also produced bronchoconstriction. This suggested that the lack of response to the administration of nebulised water after being given salbutamol was not because there was a refractory period after the original bronchoconstricting challenge. Hypo-osmolar solutions cause the release of histamine from mast cells ${ }^{24}$ and we presume that this may be the cause of the bronchoconstriction seen in our infants, the histamine acting either directly on the smooth muscle or by reflex action on the vagus nerve.

During the studies some of the infants seemed clinically worse immediately after the administration of salbutamol. After completing the study we looked at a further 17 infants all of whom gave a history of wheezing. ${ }^{25}$ In 13 of the 17 infants there was a rise in airways resistance and a fall in specific conductance when they were challenged with nebulised water. They also showed significant increases in airways resistance and decreases in specific conductance after nebulised salbutamol had been given. We feel this may have been partly caused by the acid and preservatives in the solution. Until we have found out the specific cause of the paradoxical deterioration and how to eliminate it we cannot recommend the use of nebulised salbutamol at home for infants under 1 year old.

The validity of thoracic gas volume measurements in wheezy infants has recently been questioned by Godfrey et al. ${ }^{26}$ They found low thoracic gas volume measurements in wheezy infants who had had bronchiolitis that were difficult to explain. In some of our patients the measurements were surprisingly low, and they changed remarkably little during the challenge procedures.

We used the plethysmograph to look for changes in the airway function of our infants and we feel that this is a valid use of it.

We thank the Asthma Research Council of the United Kingdom for financial support.

\section{References}

1 Prendiville A, Green S, Silverman M. Paradoxical response to nebulised salbutamol in wheezy infants; assessment by partial expiratory flow-volume curves. Thorax 1987;42:86-91.

2 Polgar G, Weng TR. The functional development of the respiratory system. Am Rev Respir Dis 1979:120:625-95.

3 Galde's-Sebolt M, McLoughlin FO, Levison H. Comparison of cold air, ultrasonic mist and metacholine inhalations as tests of bronchial reactivity in normal and asthmatic children. $J$ Pediatr 1985:107:526-30

+ Allegra L. Branco S. Non-specific bronchial reactivity obtained with an ultrasonic acrosol of distilled water. Eur J Respir Dis 1980:61:41-9.

Bakan R, Levison H. Effects of ultrasonically nebulised distilled water on airway dynamics in children with cystic fibrosis and asthma. J Pediatr 1972;20:396-400.

"Schoeffel RG, Anderson SD, Altonysyan RG. Bronchial hyper-reactivity in response to inhalation of ultrasonically nebulised solutions of distilled water and saline. $\mathrm{Br}$ Med J 1981:283: 1285-7.

Anderson SD, Schocffel RG, Finncy M. Evaluation of ultrasonically nebulised solutions for provocation testing in patients with asthma. Thorax 1983;38:289-91

× Dubois AB, Botelho SY, Bedell GN, Marshall R, Comroc JH Jr. A rapid plethysmographic method for measuring thoracic gas volume: a comparison with a nitrogen washout method for measuring functional residual capacity in normal subjects. $J$ Clin Invest 1956;35:322-6.

"Radford M. Measurement of airway resistance and thoracic gas volume in infancy. Arch Dis Child 1974:49:611-5.

10 Stocks J, Levy NM, Godfrey S. A new apparatus for accurate measurement of airway resistance in infancy. $J$ Appl Physiol 1977:43:155-9

1 Helms P. Problems with plethysmographic estimation of lung volume in infants and young children. $J$ Appl Physiol 1982:52:995-9.

12 Rutter N, Milner AD, Hiller EJ. Effect of bronchodilators on respiratory resistance in infants and young children with bronchiolitis and wheezy bronchitis. Arch Dis Child 1975:50:719. 
${ }^{13}$ Lenney W. Milner AD. Nebulised sodium cromoglycate in the preschool wheezy child. Arch Dis Child 1978:53:474-6.

14 Lenney W. Milner AD. At what age do bronchodilator drugs work? Arch Dis Child 1978;53:532-5.

15 Lenney W. Milner AD. Alpha and beta adrenergic stimulants in bronchiolitis and wheezy bronchitis in children under 18 months of age. Arch Dis Child 1978:53:707-9.

16 Henry RL. Hiller EJ, Milner AD. Hodges IGC, Stokes GM. Nebulised ipratropium bromide and sodium cromoglycate in the first two years of life. Arch Dis Child 1984:59:54-7.

17 Hodges IGC. Groggins RC. Milner AD, Stokes GM. Bronchodilator effect of inhaled ipratropium bromide in wheczy toddlers. Arch Dis Child 1981;56:729-32.

${ }^{18}$ Geller-Bernstein C. Levin S. Nebulised sodium cromoglycate in the treatment of wheezy bronchitis in infants and young children. Respiration 1981:43:284-8.

19 Radford M. Effect of salbutamol in infants with wheczy bronchitis. Arch Dis Child 1975;50:535-9.

20 Tal A. Bavilski C. Yohai D, Bcarman JE, Gorodischer R, Moses SW. Dexamethasone and salbutamol in the treatment of acute wheczing in infants. Pediatrics 1983;71:13-8.
${ }^{21}$ Silverman M. Bronchodilators for wheezy infants? Arch Dis Child 1984:59:84-7.

22 Zeiger RS. Special considerations in the approach to asthma in infancy and early childhood. J Asthma 1983;20:341-59.

${ }^{23}$ Godfrey S. The wheezy infant. In: Meadow R, ed. Recent advances in paediatrics. Edinburgh: Churchill Livingstone. 1983:137-54.

${ }^{24}$ Haliner M, Austen HF. Cyclic AVP, ATP and reversed anaphylactic histamine release from rat mast cells. $J$ Immunol 1974:112:664-74.

25 O'Callaghan C. Milner AD, Swarbrick A. Paradoxical deterioration in lung function after nebulised salbutamol in wheezy infants. Lancet 1986;ii:1424-5.

${ }^{26}$ Godfrey G, Beardsmore CS, Maayan C, Bar-Yishay E. Can thoracic gas volume be measured in infants with airways obstruction? Am Rev Respir Dis 1986;133:245-51.

Correspondence to Dr C O'Callaghan. Children's Respiratory Unit, University Hospital, Nottingham NG7 2UH.

Accepted 25 October 1987 